\title{
Paraguay and Mercosur: The lesser of two evils? \\ Melissa $\mathrm{H}$. Birch \\ University of Kansas
}

Introduction

Located in the "heart of South America" between two hegemonic rivals, Argentina and Brazil, Paraguay is one of only two landlocked countries in Latin America. This mediterranean location has been the lynchpin of economic policy and international relations in Paraguay for almost a century. In fact, Paraguayan foreign policy has rested on three pillars: a commitment to the sanctity of borders and the principal of nonintervention, free navigation of the rivers that form its border on three sides and, since 1989, the defense of democracy and human rights. Thus, the decision to join the Common Market of the South (Mercosur) in 1991 represented a remarkable shift in Paraguayan foreign policy that would entail not so much bringing down barriers to trade, investment, and migration since Paraguay has been a very open economy, but building international cooperation and coordination in areas of national economic strategy, macroeconomic policy and international relations.

Regional trade agreements (RTAs) have been on the rise in recent years around the world, but Latin American interest in regional integration is longstanding. Many subregional initiatives were brought together in first Treaty of Montevideo in 1960 that established the Latin American Free Trade Association. Twenty years later a second treaty reaffirmed that commitment and created the Latin American Integration Area. Paraguay was a member of both. Within the Southern Cone, interest in creating a customs union dates from at least the 1930s and bilateral accords for cooperation on trade and infrastructure are numerous (Birch, 1992). In fact, the immediate origins of 
Mercosur can be identified in the bilateral accords established during the transition to democracy in Argentina and Brazil (Birch, 1992, 2000).

Like the North American Free Trade Agreement (NAFTA), Mercosur brings together a set of very different countries. Paraguay and Uruguay are the traditional buffer states in the region, but have little in common otherwise. Both are small compared to their larger neighbors but Uruguay has the highest per capita income of the Mercosur countries and Paraguay the lowest. Brazil, the largest country in terms of both area and gross national product, has the highest illiteracy rate among member countries and does not share a common language with the other members. Still, taken together Mercosur spans a geographic area from the equator to the South Pole, brings together more than 245 million people and represents a market almost the size of France. While the challenges are great, the potential of Mercosur to foster dramatic changes in the economic well-being and global competitiveness of the Southern Cone is significant.

After twenty years, the impact of Mercosur on Paraguay might be expected in the political, social, and economic spheres. Regional trade integration might be expected to change the pattern and products of trade, the organization of industry and commerce, and to lead to changes in the pattern of population settlement. The opportunity to create stronger linkages with larger, growing economies might be expected to lead to faster growth and fewer regional disparities. After describing the economic and political setting of Paraguay in 1991 when it signed the Treaty of Asuncion, this paper will examine the impact of Mercosur on Paraguayan economic growth and the structure of production, investment, and international trade. It will suggest that while economic change due to Mercosur might have been smaller than expected, or perhaps slower in coming, there is some sign that subtle, microeconomic pressures may be powerful agents of change. This transformation becomes evident only upon closer examination of Paraguayan trade statistics. Newly published revisions of Paraguayan statistics are the focus of the third section of this chapter. 


\section{The Starting Point}

Paraguay may be one of Latin America's most consistent followers of an openeconomy strategy for economic growth. Unlike most of its Southern Cone neighbors, Paraguay flirted with import-substitution industrialization but only briefly in the 1960s, swung toward export promotion for a similarly brief period and then proceeded to become the Southern Cone's source for imported products from extra-regional markets due to a combination of low tariffs and a stable exchange rate.(Arce, 2010) (Baer \& Birch, 1987) Long known for a thriving border trade in cities close to Argentina and Brazil, Paraguay consistently built on its position as a landlocked buffer state to garner economic benefits from neighboring countries and, during the Cold War, a staunchly anti-Communist stance to reap aid from the United States. In more recent years, the Paraguayan economy has been characterized by long periods of stagnation, punctuated by booms and busts often connected to climatic conditions. (Borda, 2011)

Paraguay did not accumulate much debt to finance its growth in the 1970 s and as a result largely escaped the debt crisis of the 1980s. Instead, Paraguay experienced rapid growth in the 1970s during the construction of the Itaipu hydroelectric facility (financed primarily by Brazil) and as its continuing drive to the East paid off with an expanding agricultural frontier at a time of relatively high commodity prices. (Baer \& Birch, 1994; M. Birch, 1992) When construction stopped and prices fell, however, the economy entered into a period of prolonged stagnation (Baer \& Birch, 1984; Barrientos Quiroga, 2007). Droughts and floods conspired with global fluctuations in commodity prices to make sustained growth elusive. See Table 1. After growing by nearly 6 percent on average during the 1970s, Paraguay entered into a period of slower and more variable growth in the 1980s that lasted for nearly two decades and from which it has only recently begun to recover. (Melissa H. Birch, 2005; Borda, 2011) See Table 2. 
During the 1980s a failing dictator groped for quick-fixes in an attempt to stave off economic decline, but a military coup in 1989 ended the 35-year rule of General Alfredo Stroessner. In the space of three years, between 1989 and 1991, Paraguay experienced the end of the Stroessner dictatorship, the end of the Cold War, and the introduction of new regional trading arrangements with the advent of Mercosur, three events that dramatically changed the political and economic environment of the country. The Colorado Party, however, continued in power and during the first decade of transition to democracy, much weaker governments tried with varying degrees of success to make economic policy in this new and more difficult political and economic context. (M.H. Birch, 1993) It was not until 2008, after sixty-one years of Colorado party rule, that power would pass peacefully for the first time in Paraguay's history to an opposition candidate, Fernando Lugo.(Abente Brun, 2011)

Unlike Argentina and Brazil, Paraguay had not experienced high inflation, a large state sector, or a protected domestic market in the years prior to 1991. Paraguay's tariffs were lower than the Mercosur average and the exchange rate had been stable, even if unrealistic, for long periods under the Stroessner regime. With the transition to democracy in Paraguay, Mercosur became an immediate political issue. The economic policy orientation of the first two democratic administrations fit well with the prevailing economic wisdom coming from Washington in the 1980s: free trade and less government intervention in the economy. It also represented policy continuity amidst so much political change. Both presidents would make modest, incremental changes to Paraguayan economic policy, but membership in Mercosur represented a fundamental change in development strategy and regional economic relations. 
Table 1

Growth of Paraguayan Economy: 1962-2010

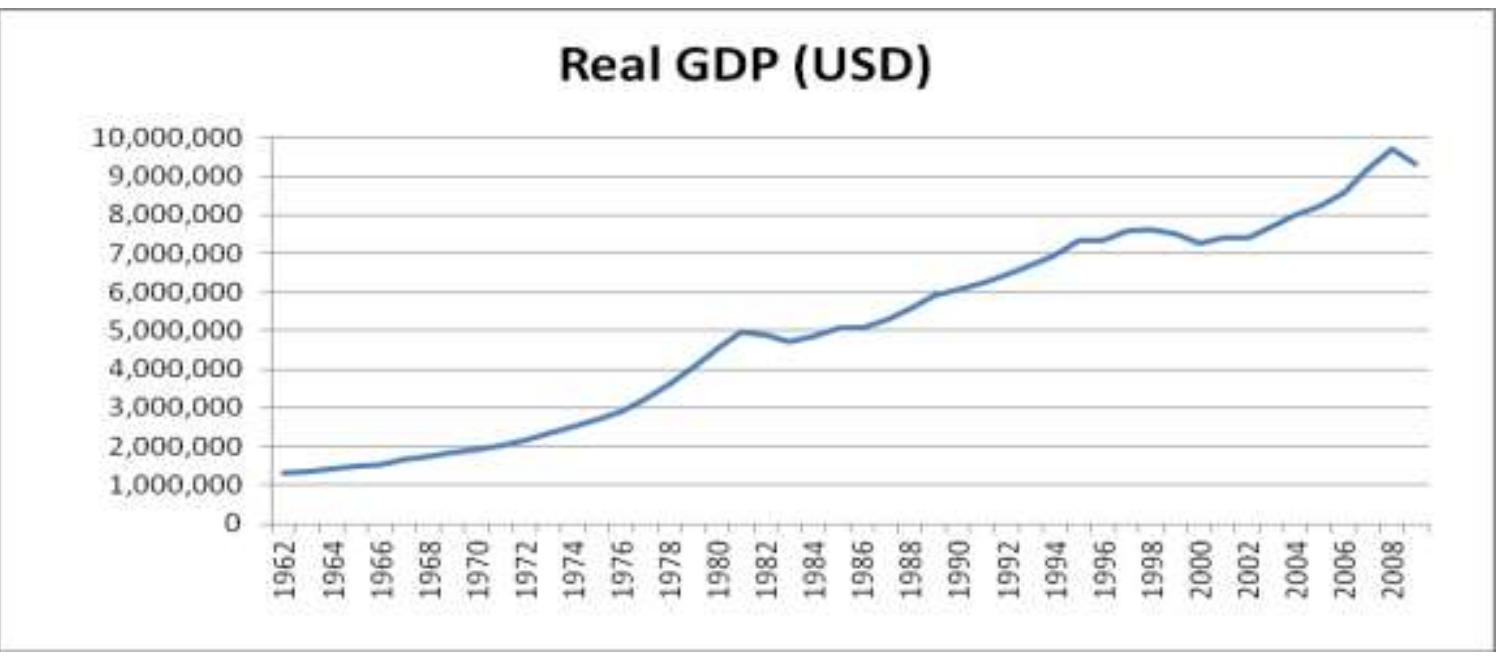

Table 2.

Paraguayan Per Capita Income: 1962-2008

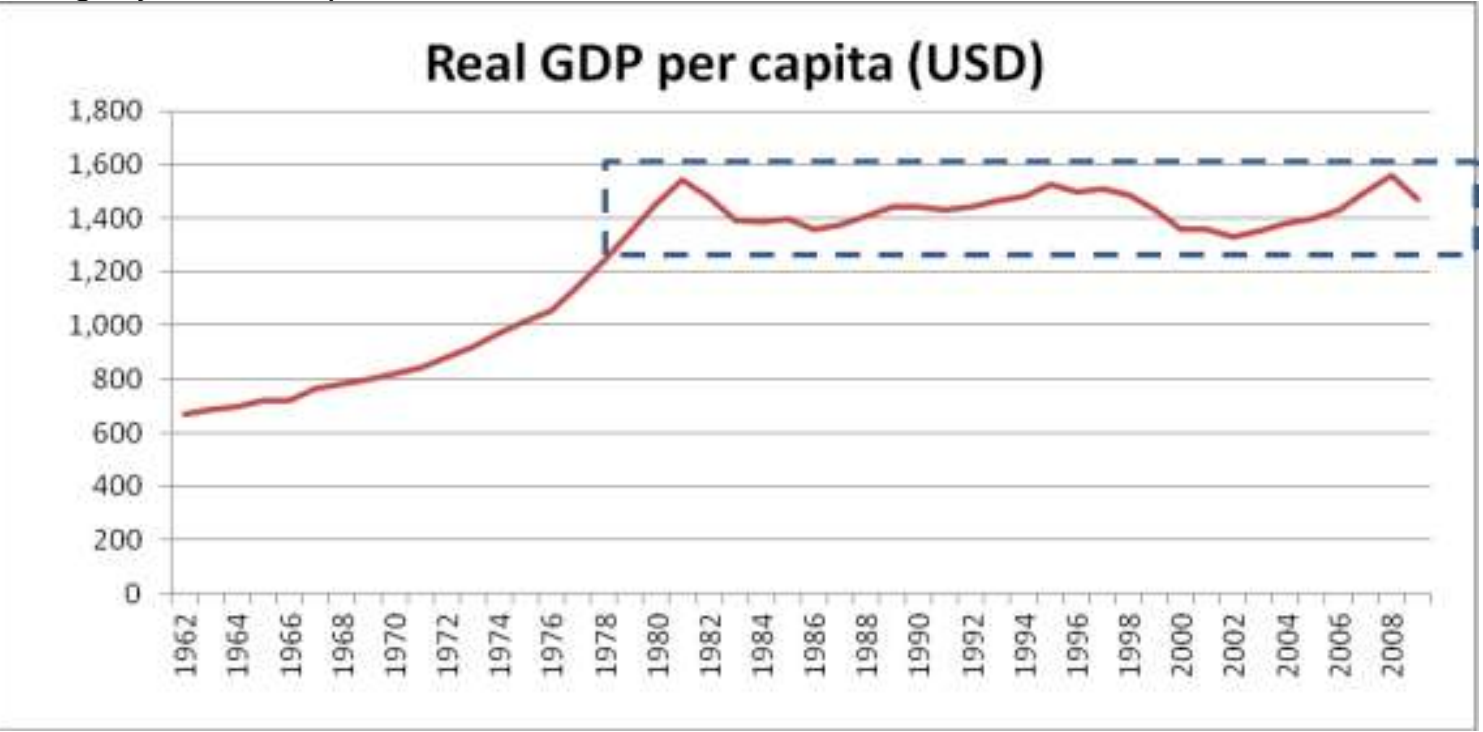

Source: CADEP, 2011 
A partnership of democratic governments, Paraguay had not been eligible for membership during the Stroessner regime, but it had been watching on the sidelines as the former rivals, Argentina and Brazil, forged stronger economic ties under the Act of Argentine-Brazilian Integration (1986), the Treaty for Integration, Cooperation \& Development (1988), and the Act of Buenos Aires (1990) which established that the countries would create a common market in four years.(Melissa H. Birch, 2000) With democratic elections completed in Paraguay shortly after the coup, the opportunity to join the regional integration project became real. However, since much of Paraguayan economic policy was based on playing Argentina and Brazil against each other, Mercosur would require a major rethinking of economic strategy. (World Bank, 1992; M. Birch, 1992)

Campesinos, workers and unions generally opposed Mercosur but they were a small and fractured group. The business community was divided on the merits of joining Mercosur. Manufacturing was a small portion of the Paraguayan economy, about 15 percent, so despite the potential threat of imports from Mercosur countries, manufacturers were not a powerful opposition. Another, more politically well-connected part of the private sector, however, would theoretically face extinction if Paraguay joined Mercosur. This was the prosperous group of merchants that made their living selling US, European and Asian imports to tourists from neighboring Argentina and Brazil where taxes and regulation made it hard to acquire such products, a result of the importsubstitution development strategy pursued by these countries for decades. In addition to low tariffs and a generally free trade stance, Paraguay's economy was well known for open borders and high levels of unregistered trade (World Bank, 1992). Mercosur represented a threat to the entrenched political and economic elites associated with these activities.

The meaningful political opposition to Mercosur came from the Arganista wing of the Colorado party and was rooted in fiercely nationalistic thinking that emphasized the 
sanctity of borders and a fear of being overtaken by the victors of the Triple Alliance War. Since the $19^{\text {th }}$ century, Paraguayan foreign policy had been wary of domination by Argentina and then Brazil. For certain groups in Paraguay, one interpretation of Mercosur was that it represented the ultimate endgame: Paraguay absorbed-at least economically--by the combination of Argentina and Brazil. (Rodríguez, 2001) Argana was assassinated in 1999 and this perspective lost political visibility but remained not far below the surface among a small but influential set of Paraguayan politicians. 1

Paraguay's Ministry of Foreign Relations urged the government to devise a new, pro-active strategy to defend the nation's interests in the upcoming Mercosur negotiations but found little interest in other parts of government. (Rachid, 2008) Mercosur would bring to an end the effectiveness of the pendulum politics strategy that had been used so effectively for more than 50 years and required the identification of a new approach (Birch, 1992, Masi, 2011). The apparent apathy on the part of government officials likely reflected less a commitment to laissez faire than incapacity to reach consensus on the design and implementation of a set of policies that would encourage the competitiveness of the private sector in this new context, one characterized by preferential market access to large, neighboring countries but more limited ties to extra-regional markets.

Suffering from economic stagnation, a fragile democratic transition, and without the tradition of proactive development management, Paraguay seems to have been incapable of designing a constructive policy response to Mercosur that would have fostered the development of a modern industrial sector. (Rodríguez, 2001) Instead, Paraguay regarded joining Mercosur as the lesser of two evils since the advantages offered by greater market access were thought insufficient to compensate for the social dislocation that it would cause and the likely end to certain commercial activities that

1 When Paraguay was suspended from Mercosur in July 2012 in the wake of the Lugo impeachment, references to the Triple Alliance resurfaced immediately and fanned nationalistic indignation. 
regional integration represented. Still, being excluded from three neighboring markets as they grew stronger through integration was not attractive either. As a result, Paraguay took few domestic policy measures to enable firms or individuals to respond proactively to Mercosur, instead acting defensively to negotiate longer lists of exceptions and longer phase-in periods for the Common External Tariff (CET). CITATION?

Over the next twenty years, the legacy of openness would continue to influence the changes in trade, investment, and overall economic activity. Yet Mercosur remains as much an issue of international relations as of economic development. As such, at critical junctures, Mercosur countries have played a decisive role in sustaining the democratic transition. At key points, Brazil, Argentina or Mercosur itself have stood with democratic forces and made it clear that Paraguay would be excluded from Mercosur if certain democratic principles were violated. A thorough analysis of the political importance for Paraguay of Mercosur is beyond the scope of this paper but it is substantial.

\section{The Economic Impacts of Mercosur}

When the Treaty of Asuncion was signed, it was hoped that Paraguay's comparative advantage in terms of cheaper land and labor might lead to its integration into the supply chain of major industrial sectors in Argentina and Brazil, fostering the formation of globally competitive clusters located in the Southern Cone that would serve the world market. Industries as diverse as automobiles and processed meat were often mentioned. Given the scale and landlocked location of Paraguayan producers, many believed their best chance for reaching global markets competitively lay in becoming part of the production process of larger Argentine or Brazilian industries that were already selling both to domestic and global customers. Were this to happen, Paraguay's pattern of production and trade would shift, investment would rise and incomes would grow 
providing a higher standard of living for Paraguayans. In this section, the data on the economy, income, investment and trade will be examined.

Impact on Income. The overarching reason for joining Mercosur was the hope that Paraguay's membership would bring average per capita income in Paraguay closer to that in the other three countries. At the time Paraguay joined Mercosur, its per capita income (\$1435 in 1991)2 was the lowest among the Mercosur countries and about one quarter of the per capita income of Mercosur's richest member at the time, Argentina. The literature on convergence(Barro, Sala-I-Martin, Blanchard, \& Hall, 1991; Sala-iMartin, 1996a), even within an RTA (Barrientos Quiroga, 2007; Sala-i-Martin, 1996b), is not very encouraging and Paraguay's experience confirms that perspective. As can be seen in Table 3a, the per capita income gap between Paraguay and its Mercosur neighbors was about 44 percent in 1990, just before Paraguay's entry into Mercosur, and stood at 56 percent in 2011 (Ruiz Diaz, 2012). Growth in neighboring countries consistently outpaces Paraguay, creating an ever-larger gap in the standard of living enjoyed across borders.

Income distribution within Paraguay has also worsened since 1991. While it would be difficult to attribute all of the change to Mercosur, it is an important feature of the Paraguayan economic context to be considered. The forces of globalization, integration and democratization over the last 20 years have brought an increase in the share of income held by the top 20 percent of the population and a decrease in that held by the bottom 20 percent of the population. A somewhat more positive view is reported in a World Bank study which found a 45 percent increase in the size of the middle class in Paraguay between 2003 and 2009. However, during the same period, the report found that the size of the middle class in Latin America as a whole grew by 50 percent. 3

2 World Bank Development Indicators, www.worldbank.org, accessed November 5, 2012.

3 Reported in Ultima Hora, November 15, 2012. Accessed at www.ultimahora.com, November 18, 2012. 
Despite significantly more attention to social programs in the most recent Paraguayan administrations, sustained progress on reducing poverty remains elusive.

\section{Table 3a:}

Paraguay and Mercosur growth rates: 1990-2011

Per capita GDP growth rates

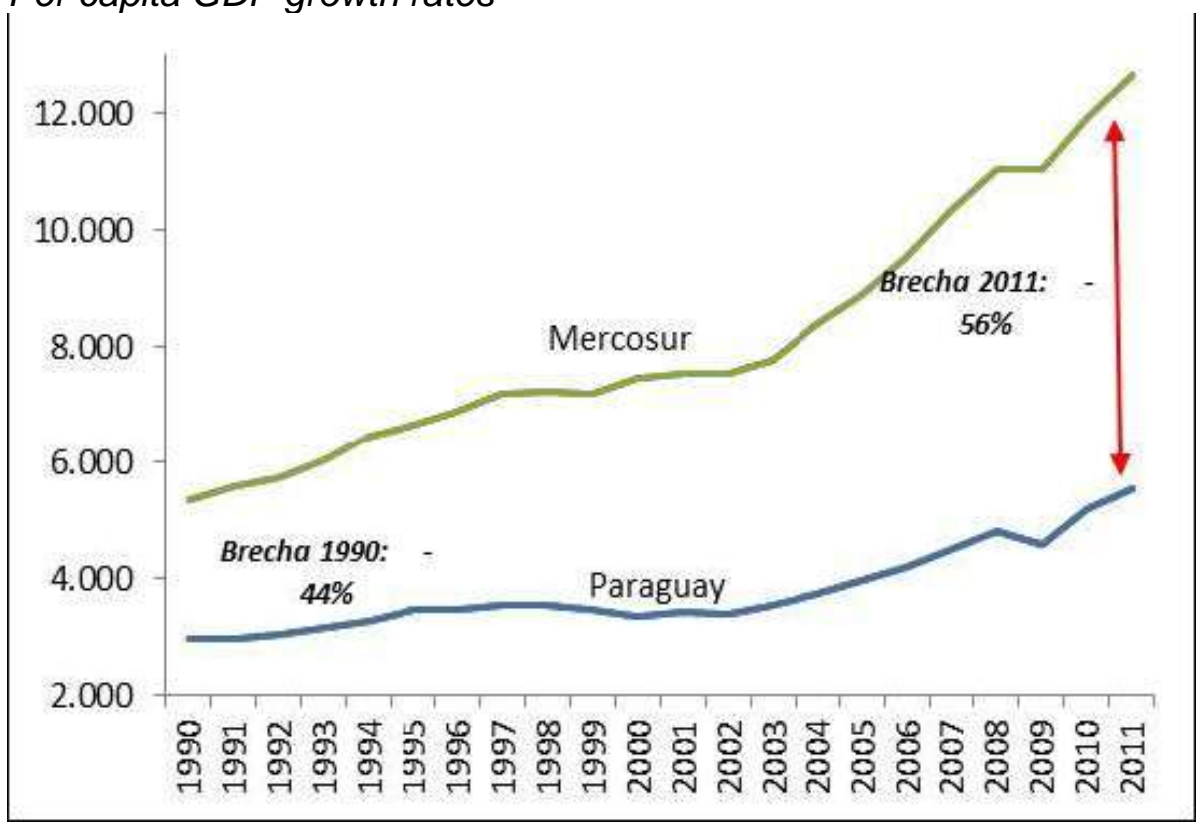

Source: Ruiz Diaz (2012)

\section{Table $3 b$}

Distribution of Income

\begin{tabular}{|l|c|c|c|c|c|c|}
\hline & 1990 & 1995 & 1999 & 2002 & 2008 & 2010 \\
\hline Gini Coefficient & 41 & 58 & 57 & 55 & 52 & 52 \\
\hline $\begin{array}{l}\text { Share of Income Held by } \\
\text { lowest 20\% of population }\end{array}$ & 6 & 2 & 2 & 3 & 4 & 3 \\
\hline $\begin{array}{l}\text { Share of Income Held by } \\
\text { highest 20\% of population }\end{array}$ & 47 & 62 & 60 & 60 & 57 & 56 \\
\hline Real GNP growth rate & 3 & 5 & -3.8 & 0 & 6 & 15 \\
\hline
\end{tabular}

Source: World Bank

On Economic Structure. One might argue that the impact of Mercosur would be seen first on the structure of the economy as winners and losers sorted themselves out in the new economic context. Here the data are more consistent with expectations; there are significant changes in the structure of production. Paraguayan manufacturing has declined as a share of total economic activity. See Table 4. Over the course of 
successive democratic regimes, there is a continuous shift toward agriculture and basic services and away from manufacturing and commerce. Brazil's devaluation in 1999 and Argentina's frequent application of surcharges and ultimate resort to import restrictions may have overwhelmed the potential benefits of lower tariffs on Paraguayan exports into these major markets.

Somewhat unexpectedly, Paraguay is a more agricultural economy today than it was in 1990.4 Hiding behind this aggregate data is a marked shift away from smallscale production of a variety of agricultural crops for both domestic consumption and export and toward large-scale, mechanized production of soybeans for global commodity markets. Between 1999 and 2010, the area devoted to soy cultivation doubled, making Paraguay the world's $6^{\text {th }}$ largest producer and $4^{\text {th }}$ largest exporter of soybeans. 5 This transformation of the agricultural sector has complicated the prospects for poverty alleviation. When combined with lingering issues regarding land tenure, the potential for political complications is high and the likelihood of constructive modernization of the sector is low.

\section{Table 4}

Economic Structure of Value Added Percentages

\begin{tabular}{|l|c|c|c||c|c|}
\hline & $\begin{array}{c}\text { Rodriguez } \\
(1989-93)\end{array}$ & $\begin{array}{c}\text { Wasmosy } \\
(1993-98)\end{array}$ & $\begin{array}{c}\text { Cubas/ } \\
\text { Gonzalez M. } \\
(1998-2003)\end{array}$ & $\begin{array}{c}\text { Duarte } \\
\text { Frutos } \\
(2003-2008)\end{array}$ & $\begin{array}{c}\text { Lugo } \\
(2008-10)\end{array}$ \\
\hline Agriculture & 15.9 & 16.5 & 18.3 & 20.2 & 19.9 \\
\hline Industry & 23.8 & 21.6 & 19.9 & 18.4 & 17.2 \\
\hline - Construction & 7.11 & 5.62 & 4.56 & 4.29 & 4.44 \\
\hline $\begin{array}{l}\text { Manufacturing } \\
\text { (Incl. Mining) }\end{array}$ & 16.7 & 16.0 & 15.4 & 14.1 & 12.8 \\
\hline Basic services & 6.86 & 7.71 & 9.07 & 10.1 & 10.9 \\
\hline $\begin{array}{l}\text { Commerce and } \\
\text { finance }\end{array}$ & 28.8 & 27.9 & 26.3 & 25.4 & 25.5 \\
\hline Other & 24.7 & 26.3 & 26.5 & 25.9 & 26.5 \\
\hline
\end{tabular}

Source: Birch (2011)

On Foreign Direct Investment. Consistent with its open economy posture, Paraguay has had a very welcoming policy toward foreign investment both before and

4 Agriculture as a share of GDP is also greater today than it was during the 20 years prior to the democratic transition. Agriculture as a share of GDP for the period 1968-88 averaged 14.2 percent, while it stood at 18.4 percent for the period 2003-10. (Borda, 2012)

5 http://commodityplatform.org/wp/wp-content/uploads/2009/06/factsheet_paraguay_final_120609.pdf 
after the Treaty of Asuncion. Legislation modernized in the early 1990s confirmed equal treatment of foreigners (Law117/91) and foreign investors have enjoyed full repatriation of capital and profits for many years (Law 60/90). There are no restrictions on conversion or transfer of foreign exchange, and Paraguay boasts among the lowest corporate and value-added tax rates in the region (World Trade Organization, 2012); Arce, 2010).

Mercosur might have been expected to make Paraguay a more attractive site for foreign direct investment (FDI) coming into Latin America given Paraguay's lower costs and now preferential access to two important Latin American markets: Argentina and Brazil. Unfortunately, the data do not demonstrate such an effect. See Table 5. There seems to be no appreciable difference between Paraguay's share of FDI going into Latin America before and after Mercosur. Even as a share of all FDI arriving in Mercosur, Paraguay's share fell from .9 percent in the 20 years prior to 1991 to .6 percent in the 20 years following.6 Paraguay's reputation for weak institutions, the absence of intellectual property protections, inadequate transportation infrastructure, widespread contraband and poor fiscal controls undermines the attractiveness of Paraguay for foreign investment. Masi (2011) notes an increase in FDI as a share of GDP entering Paraguay in the 1990s which he attributes to the restructuring of the banking and financial services sector.7 This reorganization responded more to internal issues resulting from the transition to democracy than growing regional integration.

\section{Table 5}

Foreign Direct Investment in Paraguay

Percent of millions of dollars

Source: CEPAL

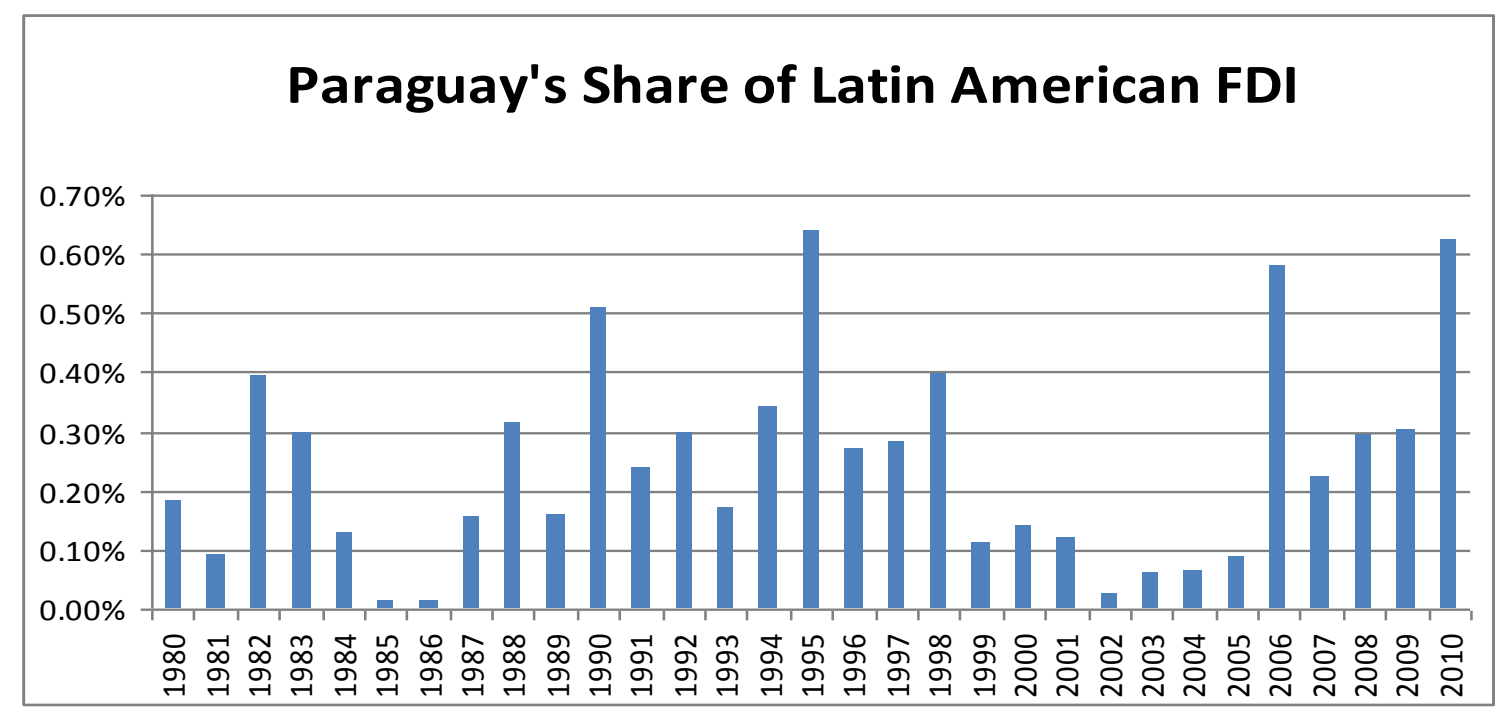

6 Author's calculation based on data from World Bank. FDI reported in current dollars.

7 Masi (2011), p. 132. 
To encourage investors to take advantage of the country's lower costs and strategic location, Paraguay passed legislation in 1997 to create an in-bond processing (maquila) facility. Paraguayan maquila operations can be located in any part of the country and in any industry. Food, motorcycles, plastics, and apparel are being manufactured for export under the maquila law, which took effect in 2000. To date, some 50 companies have undertaken operations under this program, many adding value to operations in Brazil. (Fernando. Masi, 2011) This may be an early sign of developing supply chain relationships but if so, the impact has been slow to emerge and still slight.

Reflecting the global rise in the price of minerals rather than the existence of Mercosur, incoming FDI In recent years has been attracted to the mining sector. Foreign investors are looking for titanium and gold in Paraguay, while oil exploration is set to begin shortly.8 Rio Tinto Alcan is considering an investment of some $\$ 3.5$ billion in aluminum production in Paraguay, taking advantage of Paraguay's ample supply of hydroelectric power derived from the Itaipu and Yacyreta dams on the Parana River. These are encouraging signs for growth in the industrial sector but seem to have little to do with Mercosur.

On International Trade. The most immediate and marked effect of Mercosur on Paraguay might be expected in its international trade. After the Treaty of Asuncion, exports to Mercosur partners did indeed grow more rapidly than exports to the rest of the world (Table 6a). As a share of all exports, those to Mercosur exceed exports to the rest of the world beginning in 1996 (Table 8a), some five years after the Treaty of Asuncion was signed. As might be expected, the impact of Mercosur varied across products. Regression analysis revealed that membership in Mercosur was associated with increasing exports of chemicals, vegetable oil and beef but had a negative association with cotton and little impact on apparel and soybeans.9 Paraguayan imports from Mercosur also grew faster after the Treaty of Asuncion (Table 7a) and as a share of all imports, those from Mercosur exceed those from the rest of the world beginning in 1996 (Table 8b). In the case of both imports and exports, this trend reverses itself for the years 2006-2010.

To explain this unexpected shift in the pattern of Paraguayan trade under Mercosur, a more careful analysis will be required. The openness for which the Paraguayan economy had long been known did not disappear with the signing of the

8 See www.LatinAmericanMinerals.com for information regarding gold mining at Paso Yobai. The Americasview blog at The Economist reports on the titanium find. See www.TheEconomist.com/blogs/americasview. Accessed November 7, 2012

9 Regression analysis available from the author upon request. 
Table 6a: Growth of Paraguayan Exports

Index numbers, 1970 $=100$

Source: IMF, Direction of Trade Statistics

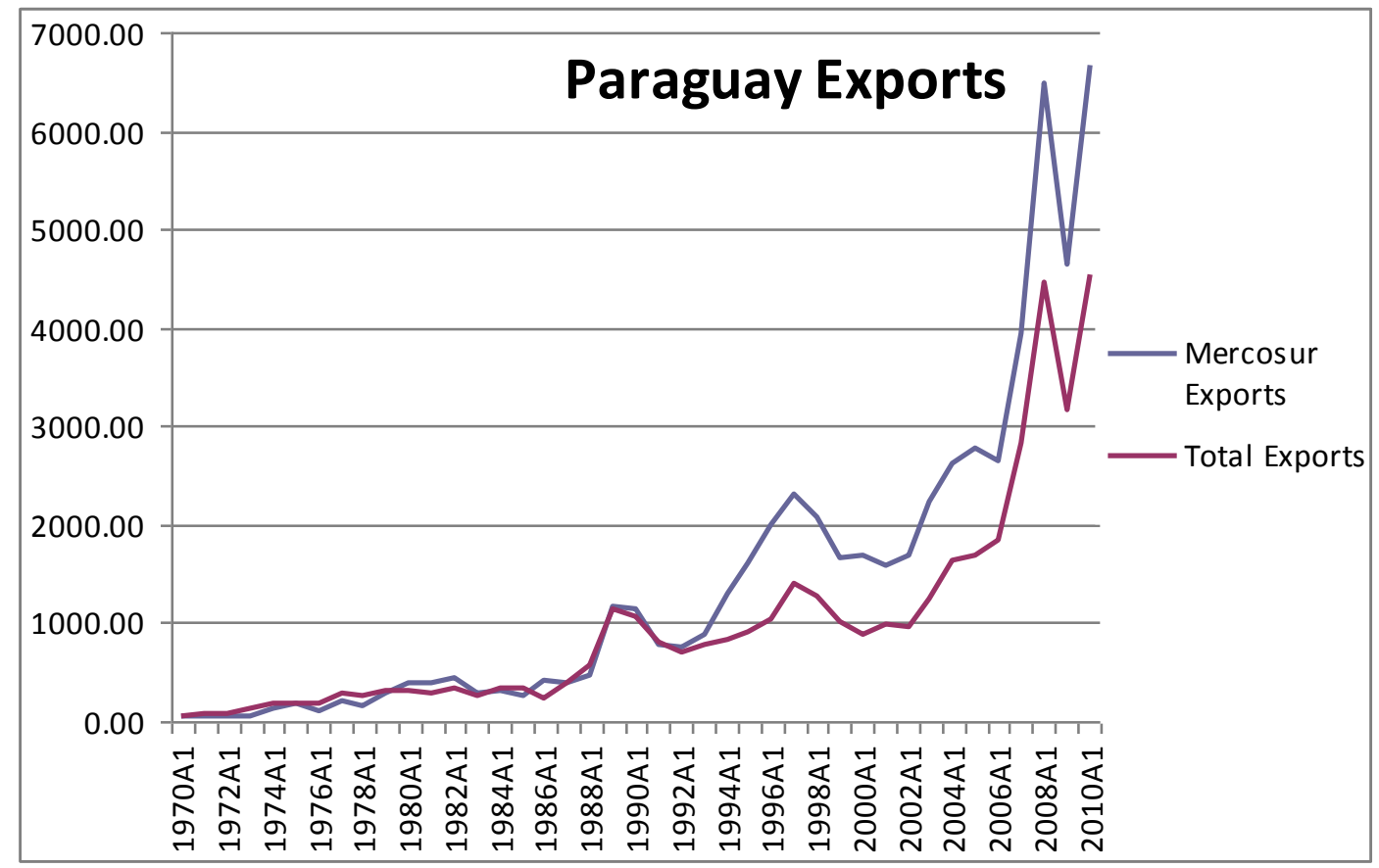

Table 6b: Paraguayan Exports to Mercosur by Country Index numbers: $1970=100$

Source: IMF, Direction of Trade Statistics

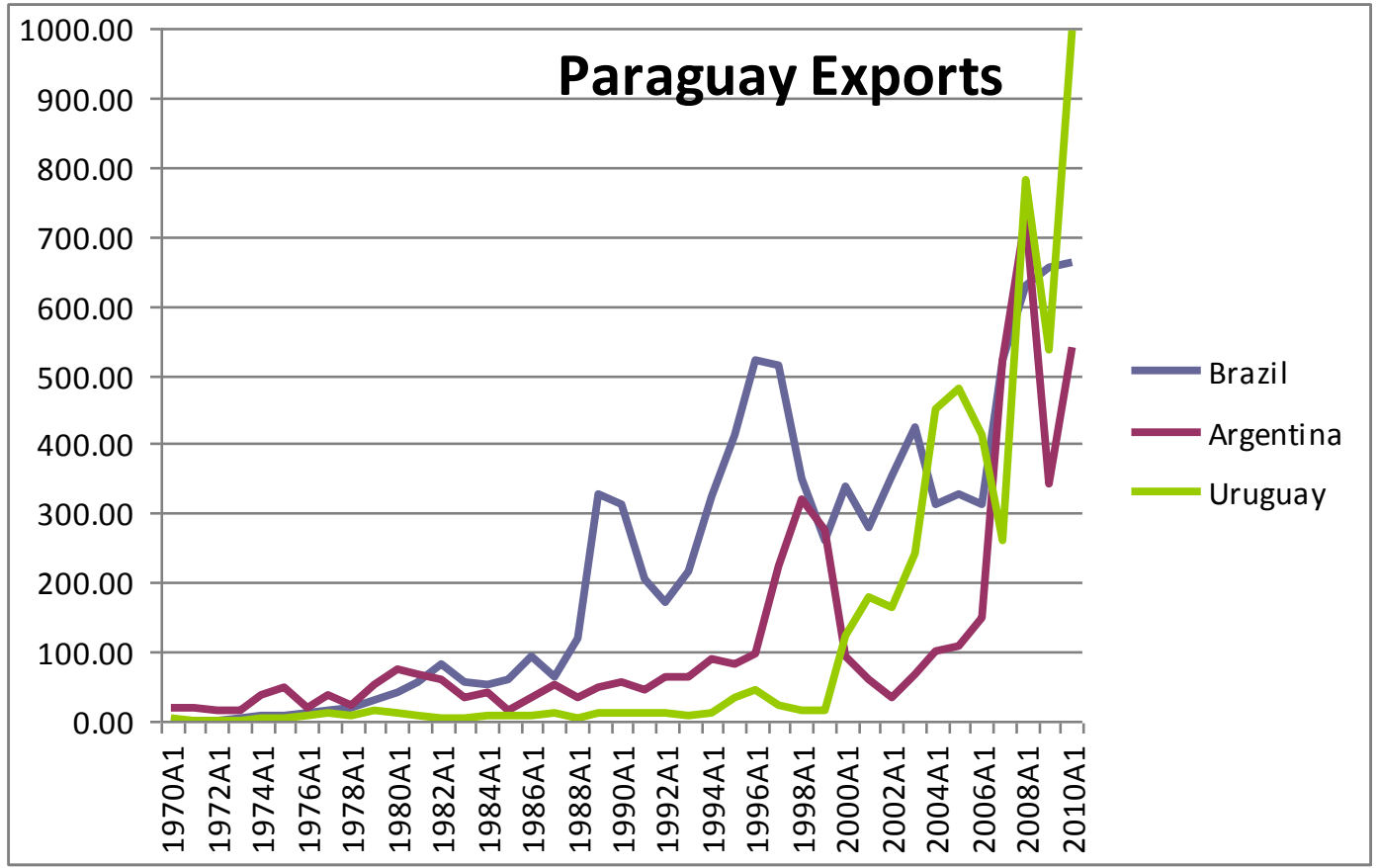


Table 7a

Growth of Paraguayan Imports from Mercosur by Country Index numbers: $1970=100$

Source: IMF, Direction of Trade Statistics

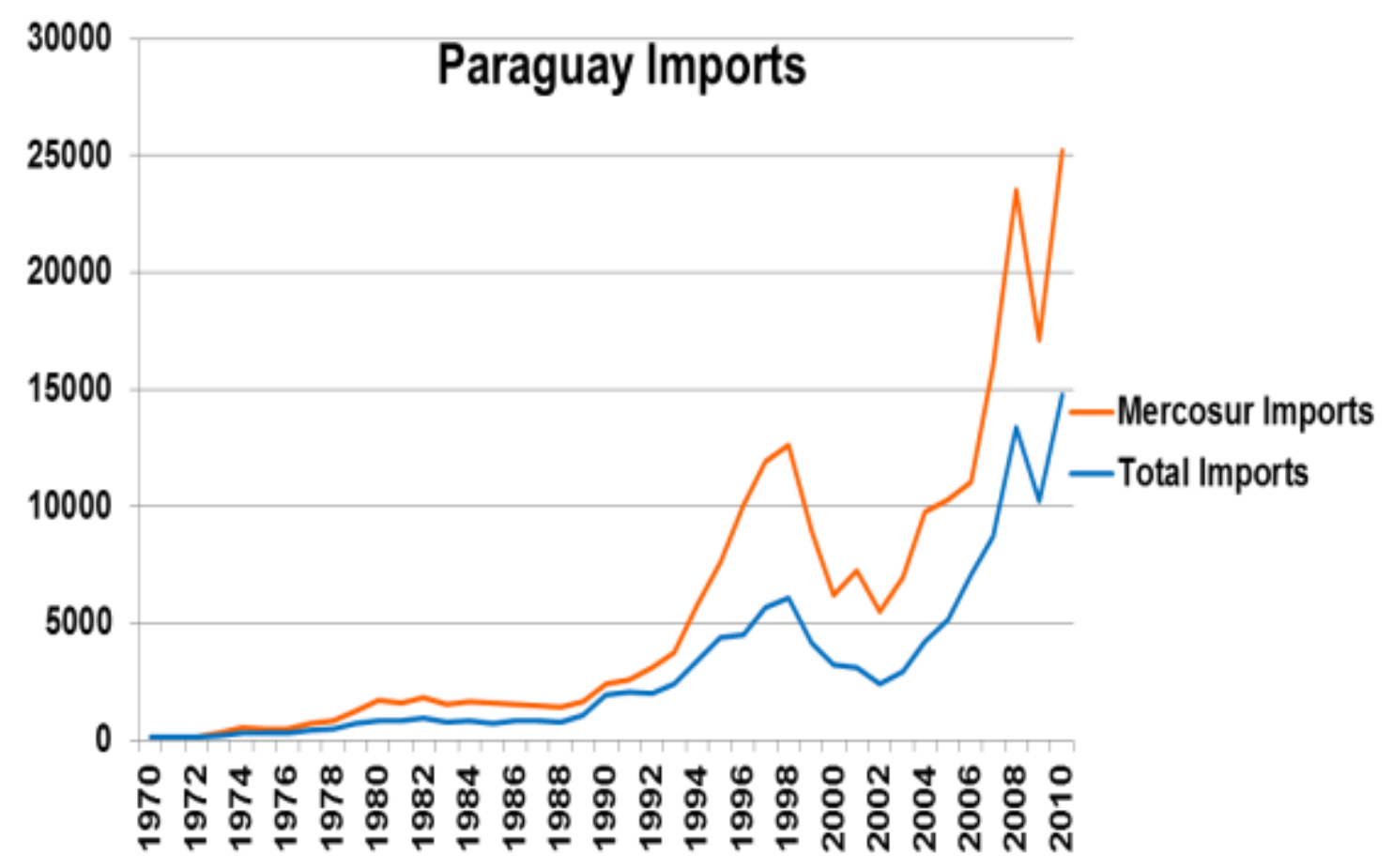

Table $7 b$

Growth of Paraguayan Imports by Country Index numbers $1970=100$

Source: IMF, Direction of Trade Statistics

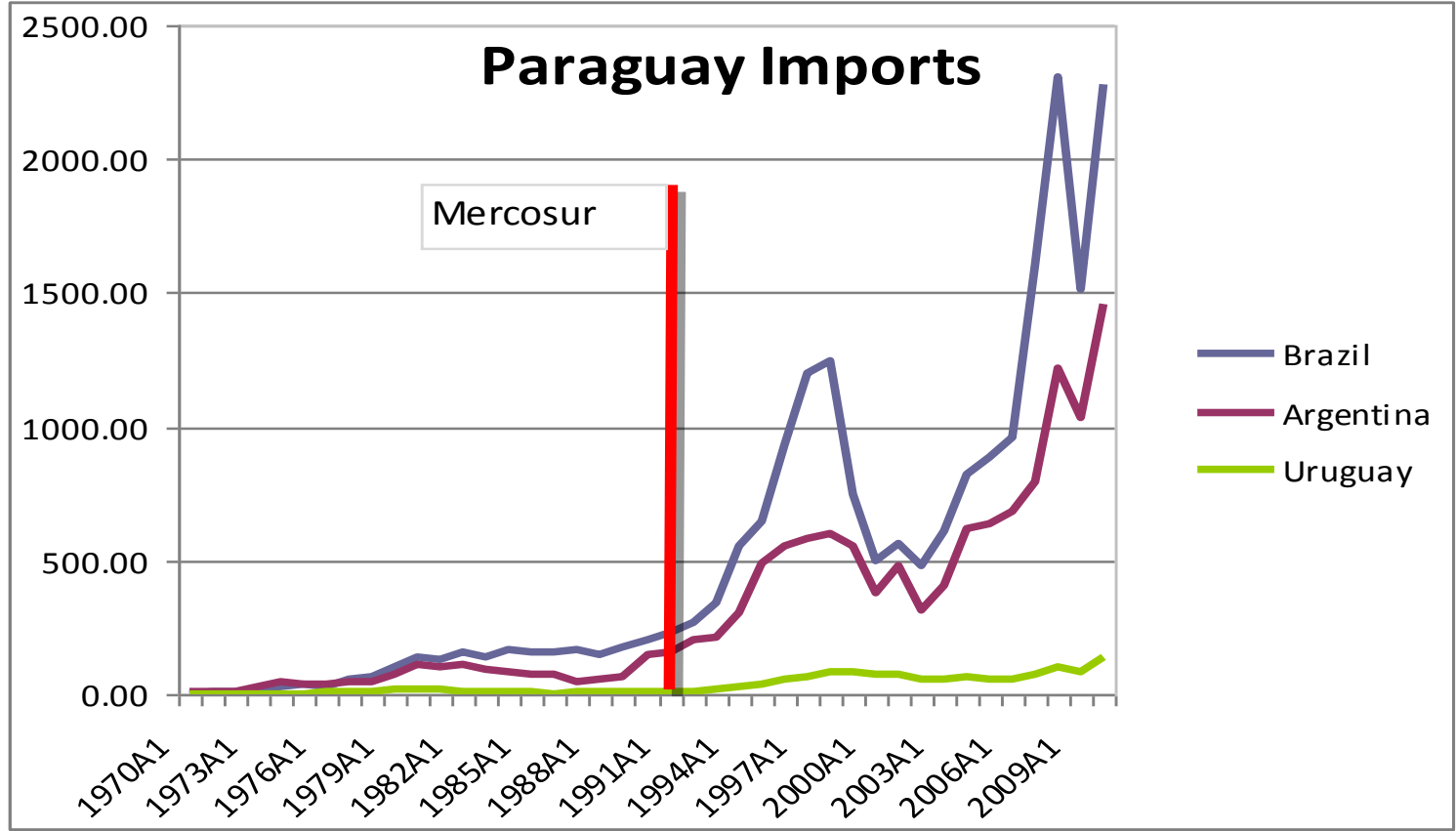


Table 8a

Paraguayan Exports: Shares to Mercosur

Source: IMF, Direction of Trade Statistics

\section{Export Shares: Mercosur \&ROW percent 1970-2010}

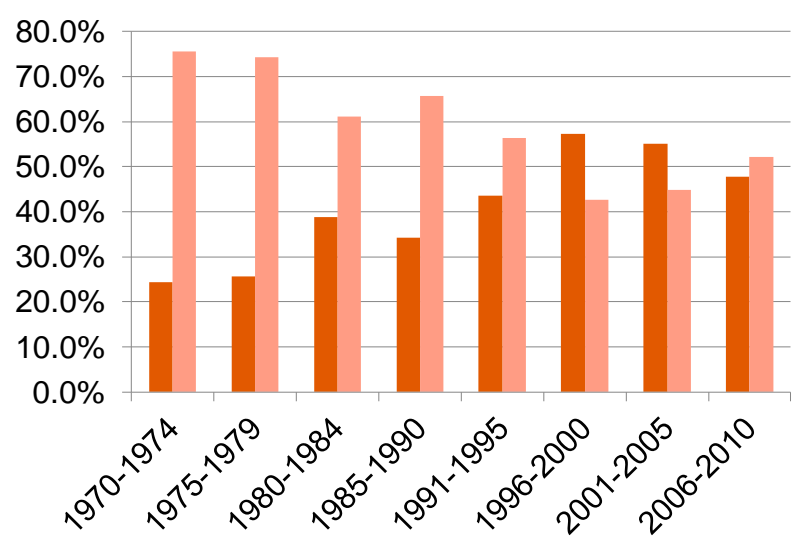

Share to

Mercosur

- Share to ROW

Table $8 b$

Paraguayan Imports: Shares from Mercosur

Source: IMF, Direction of Trade Statistics

\section{Import Shares: Mercosur \& ROW percent $1970-2010$}

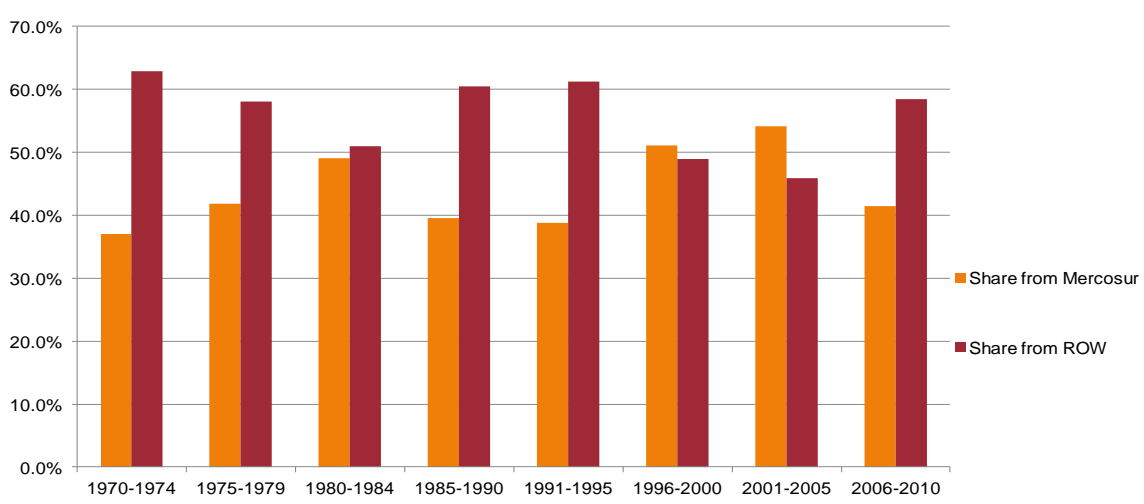


Treaty of Asuncion. In fact, much of it would be enshrined in the list of exceptions that Paraguay submitted. The inability of the Mercosur partners to come to terms with the creation of a CET also provided space for Paraguay to build on already existing markets. The next section of this chapter will discuss how the opportunity represented by Mercosur combined with existing commercial patterns in Paraguay and global trends from beyond the region to yield a unique result.

\section{The Legacy of Openness}

Reflecting the predominant share of agriculture in the economy, Paraguayan exports are heavily concentrated in primary products. Cotton, beef, tobacco and other agricultural products have been the mainstays of Paraguayan exports over the years, giving way increasingly to soybeans since the 1970s. According to official statistics, for the period 2005-2010, just three products (oilseeds, beef, and vegetable oil) accounted for 70 percent of all exports. Wheat and cereal (mostly rice) add another 10 percent. Mercosur, Europe and the associated Mercosur countries (Chile, Bolivia, Andean Pact, Israel, India and South Africa) were the top 3 destinations for Paraguayan exports.10 Given its landlocked location, most of Paraguay's commodity exports pass first through ports in Argentina and Brazil before reaching global consumers. Chile and Russia have been important markets for Paraguayan beef, but exports are often interrupted by outbreaks of hoof and mouth disease. In recent years, Paraguay has become a major supplier of organic products to world markets. In fact, Paraguay is the major supplier of organic sugar to the United States.11

On the import side, five products account for 75 percent of Paraguayan imports. All manufactured products, they are: chemicals and plastics, petroleum, automobile and auto parts, electronics, and machinery and equipment. Chemicals and plastics exceeded electronics in official statistics for the first time in 2011 . Widely used in the

10 Mercosur admitted Chile and Bolivia as observer members in 1996 and the member countries of the Andean Community were added in 2003. The Southern African Customs Union joined in 2008.

Venezuela became a full member of Mercosur in 2012.

11 http://www.datamyne.com/blog/tag/organic-sugar/ 
country's agriculture production, these imports are closely tied to the production of primary exports. Industrial imports come from China, Brazil, Argentina, the US and Venezuela. China outranked Brazil for the first time in 2011 as the source of registered imports and accounted for 34 percent of all Paraguayan imports while Mercosur accounted for 41 percent, and the EU some 5 percent.(Servin, 2011) Mercosur countries are major suppliers of a number of important industrial goods. More than twothirds of all imported petroleum products and some 80 percent of all imported food stuffs and metal products are supplied by Mercosur partners. (Swanson, 2011)

In addition to merchandise trade, the Paraguayan external sector reflects two other features of the Paraguayan economy. As the partner of both Argentina and Brazil, Paraguay exports hydroelectric power from the Itaipu and Yacyreta dams. In each case, Paraguay sells excess power to its bilateral partner at a price set in dollars and adjusted periodically according to a formula established in the treaty. In 2009 , Paraguayan power exports to Brazil amounted to $\$ 120$ million or .8 percent of its GDP. In July 2009 the government of Fernando Lugo successfully negotiated a dramatic increase in the price and terms of electricity sales to Brazil that will result in an approximately 300 percent increase in revenues received. Revenues from the sale of power to Brazil currently account for 20 percent of government revenues. 12 Almost all of the power from Yacyreta is sold to Argentina.

Finally, there is a vibrant triangle trade or re-export activity that thrives in Paraguay's border regions. As mentioned above, Paraguay's strategic location between Argentina and Brazil led to the development of a substantial border trade. In the 1960s and 1970s, regional tourism served as the driver for the sale of luxury goods (perfume, whiskey, cigarettes) from the US and Europe to tourists from Argentina and Brazil. (Baer \& Birch, 1987) During the 1980s, as the border between Brazil and Paraguay near

12 IMF (2010) accessed http://www.imf.org/external/pubs/ft/scr/2010/cr10170.pdf) on November 20, 2012. 
Ciudad del Este became the hub of construction activity associated with the Itaipu Dam, the border became much more porous and the volume of border trade exploded. Imports from Japan, principally electronics, and counterfeit brands, CDs and videotapes imported illegally or manufactured domestically were added to the product offerings. Paraguay, and particularly Ciudad del Este, garnered a reputation as the source for a wide variety of consumer goods, sold legally or illegally. In the 1990s, the new democratic Paraguayan government, facing increasing pressure from other governments, tried to gain better control over border commerce. The "regimen de turismo" was included as part of a broader tax reform, institutionalizing the process of reexports. Products sold legally under the "regimen de turismo" were eligible for a reduced tariff rate and a lower value added tax, an incentive to regularize this border trade. Electronics, toys, designer clothing, and athletic shoes were among the most frequently commercialized products under this arrangement. 13 .

Mercosur and its CET posed a significant challenge to this business in the border regions. Fortunately, as one of the disadvantaged members of Mercosur, Paraguay was permitted an ample list of products to be excluded from the CET. Instead of putting capital goods on this list, the products covered by the regimen de turismo were included in the list of exceptions and the re-export activity was preserved. In fact, by the end of the 1990s, export sales under the regimen de turismo were estimated to be three times the value of exported domestic products.14 More recently, fluctuations of the Brazilian currency have resulted in periods of boom and bust in the border trade, but it continues to represent a major source of employment and foreign exchange for Paraguay.

While this special tariff arrangement provided preferential tax treatment for these products, under-invoicing and outright smuggling of products into and out of Paraguay continues. In the last ten years, there has been increasing interest in both Brazil and 
Paraguay in finding ways to streamline the trade in electronics and eliminate contraband.(Penner, Campos, Pereira, \& Mujica, 2006) Paraguay would seek to achieve some value added in the assembly of computers and peripherals while Brazil would gain better control over its borders and its informatics policy. A recent study indicated that about 30 firms in Ciudad del Este handle a volume of export sales equal to the value of soybean exports but provide much more employment.(Penner et al., 2006) Brazil would like to integrate the Paraguayan supply chain into its larger industrial policy on informatics. Penner et.al found that Paraguayan suppliers played a key role in providing low-cost informatics, known as BIT (bienes de informatica $y$ telecomunicaciones), that furthered the Brazilian government's desire to create widespread access in Brazil to computers and telephony. He estimates that 98 percent of BIT sales in Ciudad del Este go to informal Brazilian buyers (known as sacoleiros) and the assemblers in Brazil (known as cloneiros) conduct about 99 percent of their sales in the informal sector, that is, without documentation and receipts. Cloneiro sales may account for as much as 80 percent of the Brazilian computer market. (Penner, 2006)

In an attempt to gain some control over this trade, the Lei dos Sacoleiros was passed in Brazil in September 2009 and entered into effect in January 2012.(Martello, 2012) The law will allow these small business people to import into Brazil up to $\$ 110,000$ reais (about $\$ 63,000$ ) annually, paying a single tax rate of 25 percent instead of the usual 40 percent.(Martello, 2009) Many products (arms, cigarettes, medicine, and liquor, for example) are exempt from the law, suggesting that electronics is the target of this legislation. Importers wishing to operate under this new trade facility will have to be registered firms in Brazil, requiring a substantial investment of time and money to enter the formal market.

These features of Paraguayan trade create an enormous challenge to official statistics. With the dramatic increase in soybean production, and the high proportion of 
Brazilian participation in that process, it seems likely that much of the trade identified as going to Brazil may well be soybeans destined for global markets rather than local consumption. Similarly, a large proportion of Paraguay's luxury and electronics imports from Asia are not destined for domestic consumption. Instead, they will be sold to the sacoleiros who will see they reach consumers in major urban areas in Brazil. Recently, researchers at CADEP, working with the Ministry of Finance and the Central Bank, have tried to improve the official statistics by subtracting from Paraguay's exports to Brazil the soy exports destined for world markets and adding estimates of the exports derived from the triangle trade to those reported officially.

These revised statistics from CADEP paint a very different picture of Paraguay's international trade. In 2010, official exports to Mercosur were said to account for 48 percent of all Paraguayan exports. CADEP's adjusted figures suggest that Mercosur countries were the final destination for only 29 percent of all exports, a difference of some $\$ 850$ million.15 This adjustment only accounts for soybean trade; additional work will be required to make similar corrections for other commodities such as rice and wheat. Similarly, when adjustments were made for re-export activity, Paraguay's balance of trade deficit in 2010, equal to about 30 percent of its GDP, becomes a 13 percent surplus; Paraguay's official trade deficit with Mercosur partners (equal to 19 percent of GDP using official statistics) becomes a trade surplus of 5 percent of GDP when re-exports are included.

\section{Table 9}

Paraguay: Imports and Exports for which Mercosur is major supplier/buyer Source: CADEP

\begin{tabular}{llll} 
Imports & \multicolumn{3}{c}{ Exports } \\
\hline Metal Products & $81 \%$ & Textiles and apparel & $96 \%$ \\
Food stuffs & $79 \%$ & Wheat & $91 \%$ \\
Minerals & $74 \%$ & Rice & $85 \%$ \\
Paper & $70 \%$ & Cereals & $80 \%$
\end{tabular}

15 Servin, 2010, p.5. Figures adjusted for in-transit shipments and re-exports. 
Petroleum products $\quad 69 \% \quad$ Chemicals \& Plastics $\quad 51 \%$

Using the adjusted statistics provided by CADEP that remove soybean exports bound for global markets and include extra-regional merchandise destined for Brazil, a very different picture of trade with Mercosur emerges. Acknowledging that the revised figures are a work in progress, it is possible to see that for certain Paraguayan products, Mercosur partners represent a significant market (Table 9). Unlike the official statistics, these results suggest that Mercosur is a market for a mix of agricultural and manufactured exports. Swanson's study of Paraguayan industrial exports (Swanson, 2012) revealed that Mercosur constitutes an important export opportunity for industrial producers. Industrial exports include chilled/frozen beef, vegetable oil, and leather goods but also chemicals, textiles and apparel.

If one adds the associated members (Chile, Bolivia, Venezuela, Colombia, Ecuador and Peru) to the original partners, it is clear that Mercosur is an important avenue for the growth of industrialized exports.16 A study of the Paraguayan pharmaceutical industry (Servin, 2010), for example, reveals that between 1996 and 2009 Mercosur partners accounted for about 57.7 percent of Paraguayan industrial exports and by 2009 constituted the leading market for pharmaceutical exports despite regulatory barriers facing Paraguayan pharmaceutical exports in Argentina and Brazil (Masi, 2012). Topping the list of export markets for Paraguayan pharmaceuticals was Uruguay and Mercosur associates Bolivia, Ecuador and Chile were among the top 5 destinations. Mercosur countries (Argentina, Uruguay and Brazil in that order) are also the leading suppliers (56 percent) of imported pharmaceuticals. Importantly, Argentina and Uruguay accounted for about 43 percent of the nearly $\$ 8$ million in foreign investment in the Paraguayan pharmaceutical industry in 2008.

16 According to Swanson (2012), about 47 percent of exports to associated countries consist of chilled beef exports to Chile. 
Paraguay's open economy-and open borders-have meant that international trade is a significant economic activity in the country. Official statistics capture some of this activity, but not all, and count some transactions in ways that are consistent across countries but perhaps not instructive. To understand the impact of Mercosur on the Paraguayan economy, both sets of data are necessary but the CADEP statistics are more revealing. High commodity prices in recent years have led to a dramatic increase in soybean production and exports. Less visible, but perhaps more significant, is the increase in manufactured exports that are finding a receptive market in Mercosur and associated countries. Since these exports provide more employment, more linkages within the domestic economy, and more tax revenues, their existence is noteworthy and Mercosur appears to be important for their success.

\section{Conclusion}

Twenty years after the signing of the Treaty of Asuncion which established Mercosur as the regional integration project whose goals included the free movement of goods, services, labor and capital among member countries, it is possible to see some important changes in the Paraguayan economy. The impact of Mercosur has clearly been tempered by larger, global trends and more immediate local changes. At the same time, economic integration within Mercosur has been frustratingly slow. Twenty years later, the CET remains high and imperfect. The list of exceptions is long, resulting in uneven protection. Still, it is possible to identify certain impacts that seem unlikely to have occurred in the absence of Mercosur.

Paraguay has remained an extremely open economy—formally and informally_ while developing more varied linkages within the region17. Trade with Mercosur has been growing faster than trade with the rest of the world. However, official exports to 
Brazil include commodities in-transit to global markets and under-report Paraguay's reexport to Brazil of consumer electronics from Asia. CADEP's revised statistics suggest that a true measure of Paraguayan exports to Mercosur might be four times larger than official estimates, producing a small bilateral trade surplus rather than the substantial deficit shown in official statistics. Importantly, an important share of those exports are industrialized products that create employment and economic growth in Paraguay.

Even with numerous exceptions from the CET and longer phase-in periods, Paraguay has been unable to articulate, let alone implement, a comprehensive set of public policies that would enable it to take advantage of its new ability to integrate production across national boundaries in the region. Heavily dependent on (primarily agricultural) primary products, the economy remains hostage to climatic conditions and the volatility of global commodity prices. While there are some signs of supply chains beginning to link Paraguay to more complex operations in Brazil, it remains for other authors in this volume to ascertain if Brazil or Argentina have become more globally competitive as a result of backward linkages with Paraguay. What does seem clear is that with appropriate public policies, Paraguay could take advantage of opportunities offered by Mercosur for its industrial production. In the past, however, investment, foreign or domestic, has been insufficient to restructure the manufacturing sector to take advantage of opportunities more quickly and on a larger scale. Instead, the growing weight of agriculture in the structure of the economy diverts attention from the opportunity to develop regional clusters.

As a result, there is no evidence of Mercosur leading to higher economic growth in Paraguay and thus little sign of convergence toward a higher level of per capita income for Paraguayans. While brief spurts of growth have lowered poverty rates, unfavorable climatic conditions or falling world commodity prices tend to erase those gains when economic growth falters. On average, over a longer period, the economy has tended to stagnate at a low growth threshold and the absence of investment and 
economic restructuring has denied the country a more stable, high-growth alternative. Indeed, the Paraguayan economy has become more heavily agricultural with a smaller industrial sector and the investment that has taken place, in labor-saving, mechanized agriculture and sporadic foreign direct investment in mineral exploration, seems to reflect global demand for commodities rather than opportunities derived from Mercosur.

Yet there are some subtle changes that suggest Mercosur's impact may be growing. While industrial exports are small in absolute terms, more than half of all Paraguayan industrial exports go to Mercosur markets. For producers of pharmaceuticals, plastics and processed foods, Mercosur is a major customer. Moreover, Mercosur opens doors to global trading partners. Extra-regional agreements have opened markets for Paraguay that it might have been unable to do alone and these markets are important. Not only do they enable Paraguay to diversify its export partners, they also permit new products to be exported, particularly manufactures. This broader exposure to world markets may be expected to contribute to greater competitiveness and a stronger industrial sector in the long run.

Finally, there has been important growth in just a couple of products that could bring significant changes to the structure of production and export in Paraguay. Organic sugar, organic and sustainable yerba mate, and stevia are experiencing a significant increase in global demand reflecting the growing interest in "lifestyle products" that are part of healthy consumption patterns in developed countries. This global trend may make extra-regional markets relatively more important to Paraguay over the next 20 years, but unlike soybeans and other commodities that Paraguay now exports to those markets, these organic products involve more labor and smaller scale operations. As a result, they provide income and employment for more people. To achieve the scale of production needed for major developed country markets, however, Paraguayan producers may find that linkages or alliances with Mercosur partners might be more effective than trying to go it alone. 
The first 20 years of Mercosur corresponds to a period of significant internal adjustment in Paraguay as the country transitioned to democracy after some 35 years of dictatorship. Perhaps this explains, at least in part, the absence of more marked or fundamental changes in the Paraguayan economy as a result of Mercosur, as well as the absence of appropriate public policies to amplify the opportunities. At the same time, Mercosur itself has moved forward less decisively than originally anticipated. Exchange rates still matter and non-tariff barriers still count. Deepening macroeconomic coordination among member-states will go a long way to making Mercosur a more attractive opportunity for Paraguay. 


\section{Bibliography}

Abente Brun, Diego. (2011). Hacia una democracia de calidad. In D. Borda \& D. Abente Brun (Eds.), El reto del futuro: asumiendo el legado del bicentenario (pp. 25-56). Asuncion, Paraguay: CADEP.

Arce, Lucas. (2010). Tendiendo costosos puentes: Paraguay en el Mercosur. Civitas, 10(1), 118-133.

Baer, Werner, \& Birch, Melissa. (1987). International economic relations of a small country: the case of Paraguay. Economic Development and Cultural Change ( $U S$ ), 35, 601-627.

Baer, Werner, \& Birch, Melissa H. (1984). Expansion of the economic frontier: Paraguayan growth in the 1970s. World Development ( $U K$ ), 12, 783-798.

Baer, Werner, \& Birch, Melissa H. (1994). Privatization in Latin America : new roles for the public and private sectors. Westport, Conn.: Praeger.

Barrientos Quiroga, Paola Andrea. (2007). Theory, History and Evidence of Economic Convergence in Latin America. (PhD dissertation), University of Aarhus. (No. 13/2007)

Barro, Robert J., Sala-I-Martin, Xavier, Blanchard, Olivier Jean, \& Hall, Robert E. (1991). Convergence Across States and Regions. Brookings Papers on Economic Activity, 1991(1), 107-182.

Birch, M.H. (1993). El Legado Económico de los Años de Stroessner y el Desafío por la Democracia. In D. Abente Brun (Ed.), Paraguay en Transición (pp. 31-49). Asuncion, Paraguay: CADEP.

Birch, Melissa. (1992). Pendulum Politics: Paraguayan Economic Diplomacy, 1940-75 In L. Herzog (Ed.), Changing Boundaries in the Americas (pp. 203-228). San Diego, CA: University of California at San Diego Press.

Birch, Melissa H. (2000). MERCOSUR: the Road to Economic Integration in the Southern Cone. International Journal of Public Administration, 23(5-8), 13871413.

Birch, Melissa H. (2005). La agenda económica inconclusa: (Re) creando las bases para el desarrollo económico,. In D. a. F. M. Abente (Ed.), Estado, Economía y Sociedad: Una Mirada Internacional a la Democracia Paraguaya (pp. 75-108). Asunción, Paraguay: CADEP.

Borda, Dionisio. (2011). La economia politica del crecimiento, pobreza y desigualdad en el Paraguay (1968-2010). In D. Borda \& D. Abente Brun (Eds.), El reto del futuro: asumiendo el legado del bicentenario. Asuncion, Paraguay: CADEP.

Martello, Alexandro. (2009, September 10, 2009). Sacoleiro pagara 25\% de imposto e podera importar ate R $\$ 110$ mil por ano, $O$ Globo.

Martello, Alexandro. (2012, January 31, 2012). Apos tres anos, Receita Federal regulamenta lei dos sacoleiros, $O$ Globo.

Masi, Fernando (2012). El comercio fronterizo en alerta. Economia y sociedad: Analysis de coyuntura mensual 19-21.

Masi, Fernando. (2011). Los Desafios de una Nueva Insercion Externa del Paraguay. In D. A. Borda, Diego (Ed.), El reto del futuro: asumiendo el legado del bicentenario. (pp. 115-153). Asuncion, Paraguay: CADEP.

Penner, Reinaldo (ed). (2006). Formalizacion de Empresas de Ciudad del Este. Asuncion, Paraguay: USAID and Paraguay Vende. 
Penner, Reinaldo (ed), Campos, Luis, Pereira, Carlos, \& Mujica, Marin. (2006). Segundo Informe sobre el comercio de Productos Informaticos en Ciudad del Este. Asuncion, Paraguay.

Rachid, Leila and Ruben Ramirez. (2008). Politica Exterior de la Republica del Paraguay: Herramienta para el desarrollo en un mundo globalizado (Memoria de Gestion: 2003-08 ed.). Asuncion, Paraguay: AGR Servicios Graficos.

Rodríguez, Jose Carlos. (2001). Una ecuación irresuelta: Paraguay-MERCOSUR. In G. C. De la Sierra (Ed.), Los rostros del Mercosur. El difícil camino de lo comercial a lo societal (pp. 361-372). Buenos Aires, Argentina: CLACSO.

Ruiz Diaz, F. (2012). El dilema de Tarzan: una aplicacion a las relaciones comerciales de Paraguay con el Mercosur OBEI. Asuncion, Paraguay: CADEP.

Sala-i-Martin, X.X. (1996a). The classical approach to convergence analysis. The Economic Journal, 1019-1036.

Sala-i-Martin, X.X. (1996b). Regional cohesion: Evidence and theories of regional growth and convergence. European Economic Review, 40(6), 1325-1352.

Servin, Maria Belen. (2010). Políticas regionales de Innovación en el MERCOSUR:obstáculos y oportunidades en la industria farmacéutica en Paraguay. Asuncion, Paraguay.

Servin, Maria Belen. (2011) Boletin de Comercio Exterior. Vol. No 1/2011. Enero a noviembre de 2011. Asuncion, Paraguay: CADEP.

Swanson, William. (2012). Exportaciones Industriales OBEI. Asuncion, Paraguay: CADEP.

World Bank. (1992). Paraguay: Country Economic Memorandum. Washington, DC: The International Bank for Reconstruction and Development.

World Trade Organization. (2012). Paraguay: Country Profile. (WT/TPR/S/245). Retrieved from http://stat.wto.org/CountryProfile/WSDBCountryPFView.aspx?Language=E\&Co untry=PY 